\title{
Excavating the Role of Relationship in Deshpande's through the Lens of Psychoanalysis
}

\section{OPEN ACCESS}

Manuscript ID:

ENG-2021-09023672

Volume: 9

Issue: 2

Month: March

Year: 2021

P-ISSN: 2320-2645

E-ISSN: 2582-3531

Received: 25.12 .2020

Accepted: 02.02.2021

Published: 01.03.2021

Citation:

Shelonitta, P. "Excavating the Role of Relationship in Deshpande's through the Lens of Psychoanalysis." Shanlax International Journal of English, vol. 9, no. 2, 2021, pp. 35-37.

DOI:

https://doi.org/10.34293/ english.v9i2.3672

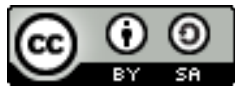

This work is licensed under a Creative Commons Attribution-ShareAlike 4.0 International License

\section{P. Shelonitta}

Anna Adarsh College for Women, Chennai, Tamil Nadu, India

\begin{abstract}
The main objective of this paper entitled Shashi Deshpande's Strangers to Ourselves: A Psychoanalytical Perspective analyzes the impact of intricate web of family and the complexities of relationships in the making of a happy family. The work also tries to capture the Man-Women Relationship and further discusses the lack of understanding in their conjugal life.

Keywords: Psychoanalysis, Lacan, Sashi Deshpande and Strangers to Ourselves.
\end{abstract}

The psychoanalyst, Sigmund Freud and Jacques Lacan, are of the opinion that when women create literature, it is inferior in comparison to that of their male counterparts because women lack the power of the 'lack' in their literature. Lacan believes that the 'phallus' signifies the symbolic language, the girl child is unable to identify herself fully with the father and so is at the disadvantage in the process of acquiring language in comparison to the male child.

Deshpande has delved into the problems of every women in this hypocritical society where she is rendered a second grade position but is expected to carry the burden of the family. The double- edges plays mayhem on her psyche. She is confused about her own role in the society and family. Deshpsnde has portrayed the inner turmoil of a women, fighting within herself, and her surroundings. The psychic imbalance stems from the unresolved love-hate relationship between mother and daughter extending to a husband and wife relationship.

Sulumavshi is a typical Indian wife to her husband Gaja. He is a dramatist and wants to write many things for his script. So Sulu allots one separate room for him. He has the habit of hearing radio news. Whenever he calls her, in spite of all her work, she joins with him to watch the news. He spends his money for his daughter and his wife, but he never spends his precious time with his family. Mathu loves Abbas and no one accepts her love, but Gaja supports their marriage and put signature in the witness paper. He does many things to his daughter but she does not realize his love.

Aparna's past life is not the onely reason for her to avoidance to hari, but her parent's marriage also a reason. Her father is Gavi Dandekar, who is also called as Gavi, Gaja, Baba and her mother is Sulumavshi. Both lead a peaceful life, until she comes to know that Gaja is having an illegal relationship with a women. She witnesses this and makes her to think badly about marriage; and draws to a conclusion that marriage life is a problematic one. These two incidents penetrated a deep scar in her mind and have an aversion to marriage. 
Sulumavshi is affected by cancer. In her death bed Gaja comes to see her, out of love. He cries a lot and cannot think his life without his wife. He often says to Aparna "You are your mother's daughter". It means that Sulu is not spending her last time with her husband. Like that Aparna also does not near to him when he is dying. She is with her boyfriend when he gets a heart attack. She comes back, and she finds, Baba died. And I never went back. His problem is his past memories especially his illegal relationship haunts him a lot. This failure of her parent's life is the reason for Aparna's failure in her life and afraid of marriage life.

Ahalya, Gaja's grandmother comes in the subplot of this novel. It is interconnected with the problem of the main characters in this novel. She is born among many siblings, but her only companion is her brother Mukund. He is the one who supports her in her life time. She says about the characters in the book that is written by her as "these were not people in a book, they were my family, my blood relations, my brothers and their children". It shows that she writes this book to convey her inner suffering to this world but not to write for entertainment. On her wedding day she gets her periods, and her marriage is stopped. Hence her father's friend agrees to marry her. If the marriage does not take place the society will think badly about her. He marries her and his name is Balasaheb.

Ahalya's first husband is a caring man. In her time child marriage is prevalent in her place. Her husband is waiting till her age fifteen. When she is sixteen her son is born. He has broken all the customs of his society for the welfare of his wife. They have a good bond between each other. She is leading her life happily with her husband. He changes her life into an unbelievable one. But her happiness is not a permanent one, she loses her husband. The society blames her so that she plans to commit sati. But she cannot, because she has a son. Her life changes after her husband's death. Her father-in- law is a cruel man. He separates her son from her. He pushes her into the widow home.

In India the cultures are interlocked with one another. Only one marriage will be acceptable in this country. Second marriage is seen as a sin for a woman. But here she takes another life to prove her in this world. She meets a painter and he does whatever she needs. He knows about her past life and marries her. Later she finds that his desire for having children and wife in his home and they have two daughters. He knows her goal and finds one job for her to teach in school. He is a good painter he wants to paint his wife but he does not do that. Their marriage life is in harmony.

Deshpande provides one Greek story in this novel and it is about a couple. In the myth also man and woman relationship is a strange one. A man musician, who loves his wife so much that he, goes to the underworld to bring his wife back. He charms the king of the underworld with his music and wins the right to take his wife away. There is one condition that he should not look back. He is careful until he comes out of the underworld into the sunshine. Then, to make sure she is following, he looks back and she has gone and he can never get her back. This story is interconnected with the characters life. Men are suspicious about the character of women in their life. Beginning part is luscious and later part ends repugnantly. It reveals the mentality of men in the recent society. It secretly says the problem of men in this novel. No one is having steady and secure thoughts in their heart. A person does not have the stable self; they cannot take their own decision, and always find faults with other person.

Past memories had played a major role in the life of Hari to accept Aparna as his wife. Hari's father has a great travel agency. As Hari's mother is no more, his father has a second marriage. Hari does not like this attitude of his father. He never thinks about his son and does not respect his feelings. As a result, Hari goes to live with his grandparents. It affects him mentally and he does not want to repeat the same mistake to Aparna. He loves her in a sincere way. He cannot digest his father's behavior which has a great impact of his character development.

Deshpande's characters are affected by their past memories. It sharpens and tames the personal growth of the characters. As that past memories and the family background are the main reasons for their problems in their life. They cannot lead their life because of those disturbing and unforgettable thoughts. Psychological problem makes them to do the dysfunctional behavior things like insecurity, 
loneliness and isolation. Through the characters of Aparna, Hari, Sulu, Gaja and Ahalya comes to know that, they suffer a lot in their life, because of the past bitter life. Their parent's lives are also the reasons for them to face those situations. Thus marital happiness and success are two abstract concepts; in which the meanings change from couple to couple and person to person. Their hard part of life becomes barrier for them to lead a life and finally their life ends in a failure one.

Deshpande's women have learned to fight against oppression at least for the manipulations of the androcentric culture that constantly wishes to dehumanize women-mother or daughter. She portrays sensitively the agony of the mother and the trauma of the girl. In her works, the implications of being a mother and having a mother are quite different. As a mother, the woman is expected to make all types of sacrifices for others. The mother image is revered all over the world but she is not a true partner in the act of procreation. She is a slave to her husband and she has to satisfy the physical needs. Woman here is presented in all her races, but mainly as a mother, a wife and a beloved. Her stories are seized with the problem of violence on women both at physical and psychological levels.

\section{References}

Assoun, Paul-Laurent. Lacan. Presses Universitaires de France, 2019.

Deshpande, Shashi. Strangers to Ourselves. HarperCollins Publishers, 2015.

Fink, Bruce. The Lacanian Subject: Between Language and Jouissance. Princeton University Press, 1995.

Julien, Philippe. Jacques Lacan's Return to Freud: The Real, the Symbolic, and the Imaginary. Translated by Devra Beck Simiu, New York University Press, 1994.

Radhika, P., and K.B. Glory. "Shashi Deshpande's "Strangers to Ourselves " as a Novel of Complex Inexplicable Marital Relationships." International Journal of English and Literature, vol. 8, no. 3, 2018, pp. 123-126.

Sawant, Tukaram S. "Shashi Deshpande's 'Strangers To Ourselves': A Story of Inexplicable Marital Relationships." Scholarly Research Journal for Humanity Science \& English Language, vol. 3, 2016, pp. 4090-4095.

Sukumar, Sneha K. "Woman of substance - Shashi Deshpande talks about her new novel strangers to ourselves." Deccan Chronicle, 2016.

\section{Author details}

P. Shelonitta, Anna Adarsh College for Women, Chennai, Tamil Nadu, India

Email ID: shelonitta1697@icloud.com 